\title{
Meta-Analysis of the ACE Gene Polymorphism in Cerebral Infarction
}

\author{
Hong-miao Tao, Bei Shao, Guo-zhong Chen
}

\begin{abstract}
Background: The angiotensin-1 converting enzyme (ACE) gene is known to have two polymorphic alleles insertion/deletion( I/D). People with the DD genotype have been shown to be at greater risk of cerebral infarction, but only in some studies. Identification of cerebral infarction susceptibility genes and quantification of associated risks have been hampered by conflicting results from underpowered case-control studies. This meta-analysis was made to look specifically into the genetics of cerebral infarction among Han Chinese population. Methods: Genetic associations studies published from January 1, 1990 to December 30, 2007 were collected from databases of MEDLINE, EMBASE, CBM and CNKI. Data were extracted using standardised forms and pooled odds ratios (ORs) with $95 \%$ confidence intervals (CIs) were calculated. Results: Twenty-nine original case-control studies of Han Chinese population, comprising 3654 patients with cerebral infarction and 3058 controls were included in the meta-analysis. Using the random effects model, the pooled ORs of ACE DD genotype VS ID+ II was 1.91 (95\% CI 1.56 to 2.34, P $<0.00001$ ). Conclusions: These data suggest that the ACE DD genotype may be a risk factor for cerebral infarction in Han Chinese population. A large scale casecontrol study is needed to clarify the functional effect of the polymorphism of the ACE I/D gene in the pathogenesis of cerebral infarction in Han Chinese population.
\end{abstract}

RÉSUMÉ: Méta-analyse du polymorphisme du gène de l'ECA dans l'infarctus cérébral. Résumé : polymorphes insertion/délétion (I/D) dans le gène de l'enzyme de conversion de l'angiotensine 1 (ECA). Certaines études ont montré que les individus qui possèdent le génotype DD ont un risque plus élevé d'infarctus cérébral. L'identification de gènes de susceptibilité à l'infarctus cérébral et la quantification des risques qui y sont associés ont été entravées par les résultats discordants d'études cas-témoin dont la puissance était insuffisante. Cette méta-analyse a été effectuée pour examiner spécifiquement la génétique de l'infarctus cérébral dans la population chinoise Han. Méthodes : Les études d'association génétique publiées entre le 1er janvier 1990 et le 30 décembre 2007 ont été identifiées dans les bases de données MEDLINE, EMBASE, CBM et CNKI. Les données ont été extraites au moyen de formulaires standardisés et nous avons calculé les rapports de cote (RC) pondérés et les intervalles de confiance à 95\% (IC). Résultats : Vingt-neuf études originales cas-témoins de la population chinoise Han comprenant 3654 patients atteints d'un infarctus cérébral et 3058 témoins ont été inclus dans la méta-analyse. En appliquant le modèle d'effet aléatoire, le RC pondéré du génotype DD par rapport au génotype ID + II était de 1,91 (IC à 95\% de 1,56 à 2,34; p < 0,00001). Conclusions : Selon ces données, le génotype DD du gène de l'ECA peut être un facteur de risque de l'infarctus cérébral dans la population chinoise Han. Une étude cas-témoin de grande envergure sera nécessaire pour clarifier l'effet fonctionnel du polymorphisme I/D du gène de l'ECA dans la pathogenèse de l'infarctus cérébral dans la population chinoise Han.

Can. J. Neurol. Sci. 2009; 36: 20-25

Ischemic stroke is a leading cause of death and disability worldwide. ${ }^{1}$ Despite recent advances in acute stroke therapy, effective prevention is an important strategy to reduce the overall burden of stroke worldwide. Established causal risk factors such as hypertension and smoking are estimated to account for $50 \%$ of vascular disease risk. Therefore the identification of novel markers of stroke risk is of key importance, both for risk prediction and potential modification to reduce future events. The angiotensin-converting enzyme (ACE), a key enzyme in the renin-angiotensin system, plays an important role in vascular wall homeostasis..$^{2-4}$ Regulation of circulation and probably tissue ACE activity are under strong genetic control. The ACE gene located on chromosome 17q23 has an insertion/deletion (I/D) polymorphism in the noncoding region of the gene. The insertion that gives rise to the I allele is an Alu repeat 4 in intron 16 of the ACE gene; the D allele results from the absence of the above insertion. Alu repeats are transponson related repeats about 250-300 base pairs long and unique to the genome of primates and have been implicated in various diseases. It has been shown that higher serum ACE activity is present in subjects

From the School of Medicine, Jinhua College of Profession and Technology (HMT, GZC), Jinhua; Cerebrovascular Department, the First Affiliated Hospital, Wenzhou Medical College (BS), Wenzhou 325000, Zhejiang Province, The People's Republic of China.

Received May 21, 2008. Final Revisions Submitted July 7, 2008. Correspondence to: Bei SHAO. Cerebrovascular Department, the First Affiliated Hospital, Wenzhou Medical College,Wenzhou 325000, Zhejiang Province, The People's Republic of China. 
with the D compared with the I allele. Numerous studies have reported a positive or null relation between the $\mathrm{D}$ allele and cerebrovascular diseases, but findings have been controversial. The sample sizes of these studies in Han Chinese population have been relatively small. Identification of stroke susceptibility genes and quantification of associated risks have been hampered by conflicting results from underpowered case-control studies. One independent meta-analysis suggested $58 \%$ increase in risk of cerebral infarction in Han Chinese population. That meta-analysis included only 2066 individuals. ${ }^{5}$ With the publication of several more recent studies, the present metaanalysis is needed. To clarify the varying results of ACE I/D, we have undertaken a meta-analysis of ACE polymorphism and cerebral infarction among Han Chinese population.

\section{METHODS}

\section{Data sources}

Electronic databases including MEDLINE, EMBASE, CBMdisc(Chinese Biomedical Literature analysis and retrieval system for compact disc) and CNKI (China National Knowledge Infrastructure) were searched from January 1, 1990 to December 30, 2007 for all case-control studies evaluating ACE gene polymorphism and cerebral infarction in Han Chinese population. The Medical Subject Headings terms and text words used for the search were: cerebrovascular disease, stroke, brain infarction, cerebral ischemia, angiotensin converting enzyme genes, polymorphism(s), mutation. All languages were searched. The references of all computer identified publications were searched for any additional studies, and the MEDLINE option related articles was used for all the relevant articles. In addition, a search to identify previous meta-analyses in stroke was also performed.

\section{Study selection}

The internationally recognized diagnostic criterion of cerebral infarction was applied. Neuroimaging (magnetic resonance imaging or computed tomography) had been used to confirm the diagnosis of cerebral infarction.

To be included in the meta-analysis, studies had to meet the following criteria: (1) the design had to be a case-control study; (2) the outcome had to be cerebral infarction; (3) there had to be at least two comparison groups (cerebral infarction $v$ control groups). Participants could be of any age; and (4) the genotype frequencies in the control group were consistent with HardyWeinberg equilibrium (HWE). Studies were excluded if one of the following existed: (1) hemorrhagic stroke; (2) the genotype frequency was not reported; (3) there was insufficient information for extraction of data; (4) the genotype frequencies in the control group were inconsistent with HWE; or (5) for duplicate publications, the smaller data set was discarded.

\section{Data extraction}

From each study, the following information was abstracted: first author, journal, year of publication, ethnicity of the study population, demographics, cerebral infarction definition; clinical characteristics, matching, validity of the genotyping method, and the number of cases and controls for ACE I/D genotype. Data were extracted independently and in duplicate by two investigators. The results were compared and the disagreements were resolved by consensus.

\section{Statistical analysis}

We examined the contrast of DD versus (DI + II). Data were analyzed using Review Manager, version 4.2. Heterogeneity among studies was examined with the Q, and $\mathrm{I}^{2}$ statistics. A P value of $<0.1$ was considered significant for the $\mathrm{Q}$ statistic; and $\mathrm{I}^{2}$ was interpreted as the proportion of total variation contributed by between-study variation. Based on the test of heterogeneity, a pooled odds ratio (OR) was calculated using fixed (MantelHaenszel) and random-effects models (DerSimonian and Laird), along with the $95 \%$ confidence interval (CI) to measure the strength of the genetic association. Visual funnel plot inspection and Egger regression tests ${ }^{6}$ were performed with SPSS version 12.0 to examine for publication bias. For the Egger test the significance level was set at 0.1 .

\section{RESULTS}

\section{Characteristics of included studies}

Twenty-nine original case-control studies of Han Chinese population, ${ }^{7-35}$ comprising 3654 patients with cerebral infarction and 3058 controls were included in the meta-analysis, and are profiled in the Table. Specific matching for age and sex was described in ten studies. $7,11,14,16,17,25,26,28,29,31$ None of the studies included in the meta-analysis stated that genotyping was performed blinded to clinical status. Polymerase chain reaction (PCR) based genotyping method was mentioned in each study. The distribution of the genotypes in the control group was consistent with $\mathrm{HWE}(\mathrm{P}>0.05)$.

\section{Association between ACE I/D and cerebral infarction}

Thirteen studies found a positive association between ACE I/D and cerebral infarction. . $^{7,10,11,15,16,18,21,25,27,31-33}$ Sixteen other studies reported a null association. There was significant heterogeneity among individual estimates of the ORs ( $\mathrm{Q}$ test $\mathrm{P}<0.0001 ; \mathrm{I}^{2}=57.3 \%$ ) and the original data were combined by means of random effect model. As shown in Figure 1, there was a statistically significant increase $(91 \%)$ of risk to cerebral infarction in DD genotype, compared with ID+ II $(\mathrm{OR}=1.91$, $95 \%$ CI 1.56 to $2.34, \mathrm{P}<0.00001)$.

\section{Sensitivity analysis}

As shown in Figure 2, the sensitivity analysis performed after excluding ten studies $7,11,13-15,19,23,25,27,33$ with relatively small sample size gave a pooled OR of 1.70 (95\% CI 1.34 to 2.17, $\mathrm{P}<0.0001)$. These results were similar to the results of the metaanalysis before the sensitivity analysis $(\mathrm{OR}=1.91,95 \% \mathrm{CI} 1.56$ to $2.34, \mathrm{P}<0.00001)$. The sensitivity analysis did not alter the pattern of results. So it suggested that the combined results of meta-analysis were reliable.

\section{Publication bias}

Figure 3 showed that the distribution of the ORs from individual studies in relation to their respective standard deviation was symmetric in funnel plot. This was supported by 


\section{Table: Characteristics and genotype information of published studies about the association between ACE I/D gene polymorphism and cerebral infarction}

\begin{tabular}{|c|c|c|c|c|c|c|c|c|c|}
\hline \multirow[t]{2}{*}{ No } & \multirow[t]{2}{*}{ References } & \multirow{2}{*}{$\begin{array}{l}\text { Geographical } \\
\text { location }\end{array}$} & \multirow[t]{2}{*}{ Study } & \multirow[t]{2}{*}{ Num } & \multicolumn{3}{|c|}{ Phenotype } & \multirow[t]{2}{*}{ I/D (\%) } & \multirow{2}{*}{$\begin{array}{l}\text { HWE } \\
\text { Ctrl }\end{array}$} \\
\hline & & & & & $\overline{D D}$ & $\mathrm{DI}$ & II & & \\
\hline \multirow[t]{2}{*}{1} & \multirow[t]{2}{*}{$\mathrm{Bi} \mathrm{S}^{[7]}$} & \multirow[t]{2}{*}{ Heilongjiang } & DIS & 65 & 26 & 29 & 10 & $0.62 / 0.37$ & YES \\
\hline & & & Ctrl & 82 & 15 & 39 & 28 & $0.42 / 0.58$ & \\
\hline \multirow[t]{2}{*}{2} & \multirow[t]{2}{*}{ Song $\mathrm{YL}^{[8]}$} & \multirow[t]{2}{*}{ Liaoning } & DIS & 117 & 46 & 34 & 37 & $0.54 / 0.46$ & YES \\
\hline & & & Ctrl & 41 & 6 & 18 & 17 & $0.37 / 0.63$ & \\
\hline 3 & $\mathrm{Xu} \mathrm{YB}^{[9]}$ & Zhejiang & DIS & 65 & 15 & 23 & 27 & $0.41 / 0.59$ & YES \\
\hline & & & Ctrl & 117 & 16 & 45 & 56 & $0.33 / 0.67$ & \\
\hline 4 & $\mathrm{He} Y S^{[10]}$ & Shanghai & DIS & 134 & 43 & 69 & 22 & $0.58 / 0.42$ & YES \\
\hline & & & Ctrl & 124 & 24 & 65 & 35 & $0.46 / 0.54$ & \\
\hline 5 & Chen $\mathrm{XL}^{[11]}$ & Shandong & DIS & 55 & 25 & 17 & 13 & $0.60 / 0.40$ & YES \\
\hline & & & Ctrl & 41 & 9 & 17 & 15 & $0.43 / 0.57$ & \\
\hline 6 & Qiu $X^{[12]}$ & Zhejiang & DIS & 116 & 13 & 56 & 47 & $0.35 / 0.65$ & YES \\
\hline & & & Ctrl & 51 & 4 & 23 & 24 & $0.30 / 0.70$ & \\
\hline 7 & Shi GF ${ }^{[13]}$ & Jiangsu & DIS & 76 & 30 & 36 & 10 & $0.63 / 0.37$ & YES \\
\hline & & & Ctrl & 30 & 8 & 12 & 10 & $0.47 / 0.53$ & \\
\hline 8 & Zhang $C^{[14]}$ & Shandong & DIS & 58 & 12 & 24 & 22 & $0.41 / 0.58$ & YES \\
\hline & & & Ctrl & 60 & 9 & 27 & 24 & $0.38 / 0.62$ & \\
\hline 9 & Cui TP ${ }^{[15]}$ & Hubei & DIS & 58 & 17 & 32 & 9 & $0.57 / 0.43$ & YES \\
\hline & & & Ctrl & 82 & 11 & 42 & 29 & $0.39 / 0.61$ & \\
\hline 10 & Zhang $X^{[16]}$ & Zhejiang & DIS & 165 & 71 & 76 & 18 & $0.66 / 0.34$ & YES \\
\hline & & & Ctrl & 106 & 18 & 51 & 37 & $0.41 / 0.59$ & \\
\hline 11 & Zhao $Y^{[17]}$ & Beijing & DIS & 294 & 38 & 114 & 112 & $0.37 / 0.63$ & YES \\
\hline & & & Ctrl & 280 & 48 & 126 & 106 & $0.40 / 0.60$ & \\
\hline 12 & Fan $\mathrm{G}^{[18]}$ & Shandong & DIS & 72 & 33 & 29 & 10 & $0.66 / 0.34$ & YES \\
\hline & & & Ctrl & 82 & 21 & 32 & 28 & $0.45 / 0.55$ & \\
\hline 13 & Yao LF ${ }^{[19]}$ & Heilongjiang & DIS & 60 & 12 & 25 & 23 & $0.41 / 0.59$ & YES \\
\hline & & & Ctrl & 62 & 7 & 33 & 22 & $0.38 / 0.62$ & \\
\hline 14 & Zhang $\mathrm{J}^{[20]}$ & Shanghai & DIS & 325 & 80 & 135 & 110 & $0.45 / 0.55$ & YES \\
\hline & & & Ctrl & 312 & 67 & 149 & 96 & $0.45 / 0.55$ & \\
\hline 15 & Gong $Y X^{[21]}$ & Shanghai & DIS & 126 & 26 & 43 & 57 & $0.38 / 0.62$ & YES \\
\hline & & & Ctrl & 301 & 28 & 132 & 141 & $0.31 / 0.69$ & \\
\hline 16 & $\mathrm{He} \mathrm{JL}{ }^{[22]}$ & Inner Mongolia & DIS & 68 & 13 & 30 & 25 & $0.41 / 0.59$ & YES \\
\hline & & & Ctrl & 100 & 16 & 38 & 46 & $0.35 / 0.65$ & \\
\hline 17 & Jiang $\mathrm{HP}^{[23]}$ & Hubei & DIS & 58 & 17 & 32 & 9 & $0.57 / 0.43$ & YES \\
\hline & & & Ctrl & 60 & 15 & 30 & 15 & $0.50 / 0.50$ & \\
\hline 18 & Pan $Q Y^{[24]}$ & Guangdong & DIS & 323 & 67 & 122 & 134 & $0.40 / 0.60$ & YES \\
\hline & & & Ctrl & 55 & 7 & 26 & 22 & $0.36 / 0.64$ & \\
\hline 19 & $Y u \quad Y^{[25]}$ & Heilongjiang & DIS & 36 & 20 & 12 & 4 & $0.72 / 0.28$ & YES \\
\hline & & & Ctrl & 34 & 9 & 13 & 12 & $0.46 / 0.54$ & \\
\hline 20 & Zhang $Y D^{[26]}$ & Jiangsu & DIS & 99 & 21 & 43 & 35 & $0.43 / 0.57$ & YES \\
\hline & & & Ctrl & 66 & 9 & 25 & 32 & $0.33 / 0.67$ & \\
\hline 21 & $\mathrm{LiX}^{[27]}$ & Tianjin & DIS & 85 & 29 & 39 & 17 & $0.57 / 0.43$ & YES \\
\hline & & & Ctrl & 50 & 9 & 18 & 23 & $0.36 / 0.64$ & \\
\hline 22 & Huo $Y^{[28]}$ & Beijing & DIS & 100 & 11 & 47 & 42 & $0.34 / 0.66$ & YES \\
\hline & & & Ctrl & 100 & 14 & 44 & 42 & $0.36 / 0.64$ & \\
\hline 23 & Luo YF ${ }^{[29]}$ & Tianjin & DIS & 80 & 22 & 35 & 23 & $0.50 / 0.50$ & YES \\
\hline & & & Ctrl & 70 & 11 & 32 & 27 & $0.39 / 0.61$ & \\
\hline 24 & $\mathrm{Yi} \mathrm{XM}^{[30]}$ & Ningxia & DIS & 96 & 14 & 42 & 40 & $0.37 / 0.63$ & YES \\
\hline & & & Ctrl & 58 & 8 & 33 & 17 & $0.42 / 0.58$ & \\
\hline 25 & Chen $\mathrm{DQ}^{[31]}$ & Beijing & DIS & 150 & 64 & 66 & 20 & $0.65 / 0.35$ & YES \\
\hline & & & Ctrl & 90 & 22 & 47 & 21 & $0.51 / 0.49$ & \\
\hline 26 & Cui $\mathrm{JH}^{[32]}$ & Guangdong & DIS & 114 & 29 & 61 & 24 & $0.52 / 0.48$ & YES \\
\hline & & & Ctrl & 76 & 10 & 32 & 34 & $0.34 / 0.66$ & \\
\hline 27 & $\mathrm{Gu} \mathrm{GH}^{[33]}$ & Jiangshu & DIS & 42 & 17 & 12 & 13 & $0.55 / 0.45$ & YES \\
\hline & & & Ctrl & 38 & 5 & 17 & 16 & $0.36 / 0.64$ & \\
\hline 28 & $\mathrm{Li} \mathrm{CM}^{[34]}$ & Guanggdong & DIS & 454 & 102 & 197 & 155 & $0.44 / 0.56$ & YES \\
\hline & & & Ctrl & 334 & 58 & 152 & 124 & $0.40 / 0.60$ & \\
\hline 29 & $\operatorname{Lv~J}^{[35]}$ & Liaoning & DIS & 163 & 40 & 67 & 56 & $0.45 / 0.55$ & YES \\
\hline & & & Ctrl & 156 & 33 & 74 & 49 & $0.45 / 0.55$ & \\
\hline
\end{tabular}

DIS (disease): patient with cerebral infarction; Ctrl: control group; HWE: Hardy-Weinberg Equilibrium

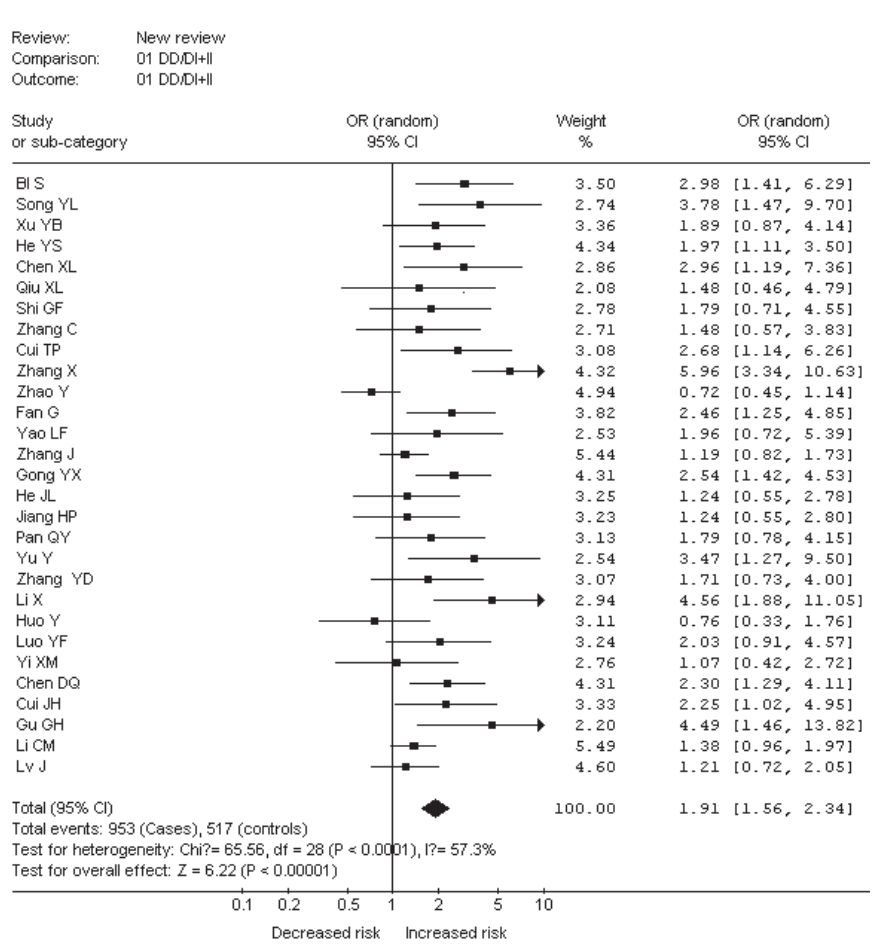

Figure 1: Forrest plot on the correlation between ACE D/I polymorphism and cerebral infarction in Han Chinese population.

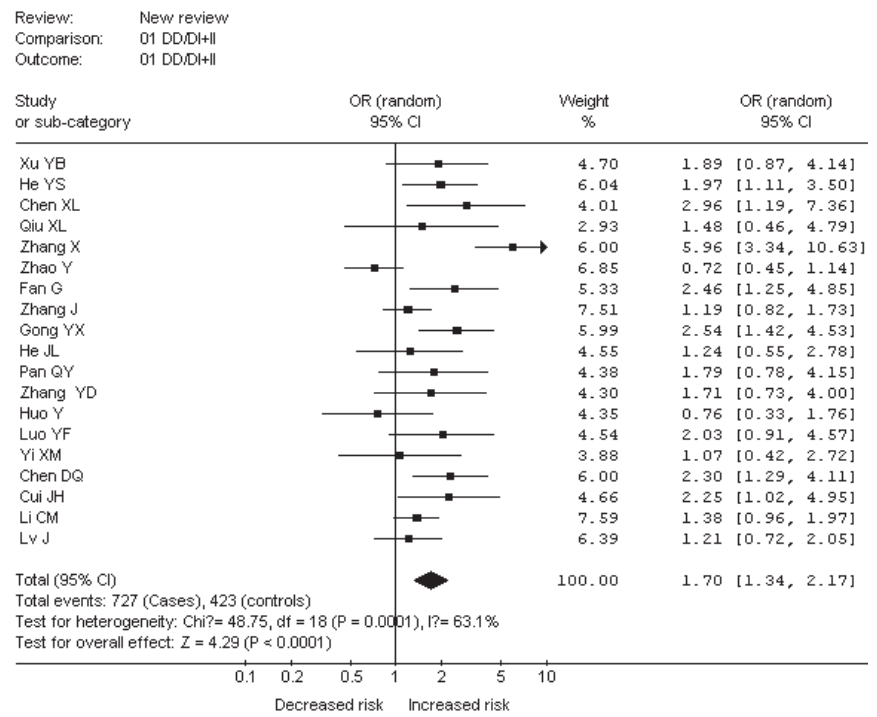

Figure 2: Sensitivity analysis ACE D/I polymorphism and cerebral infarction in Han Chinese population. 


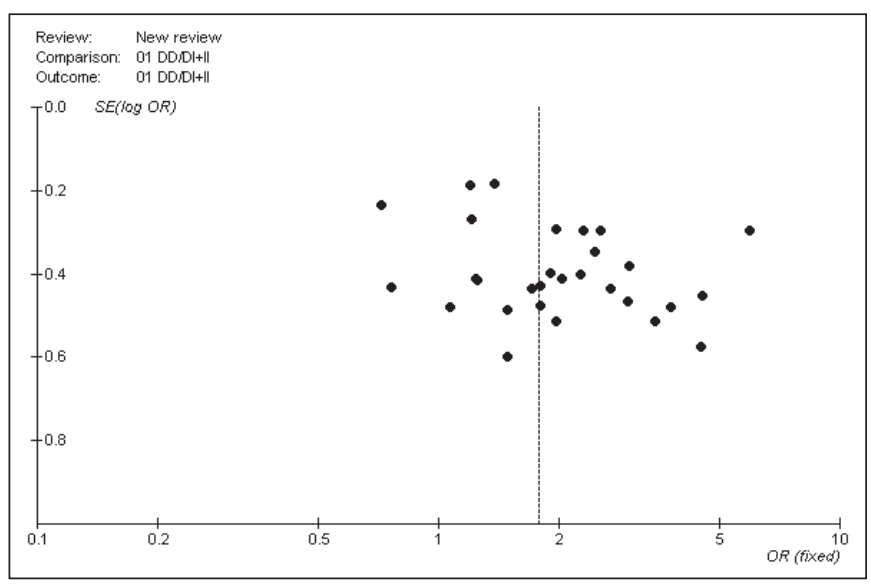

Figure 3: Funnel plot on on the correlation between ACE D/I polymorphism and cerebral infarction in Han Chinese population.

Egger regression test $(\mathrm{P}=0.801)$, which failed to detect significant bias.

\section{DISCUSSION}

The meta-analysis of relationship between gene polymorphism and disease showed that there was $91 \%$ increased risk of cerebral infarction for the variant homozygotes (DD) compared with the(DI+II) genotypes. The data from this meta-analysis clearly suggest that the ACE DD genotype is a genetic contributor to overall cerebral infarction susceptibility in Han Chinese population. We did not find evidence of publication bias either funnel plot visual inspection or Egger regression test. It suggested the combined results of meta-analysis were reliable by sensitivity analysis.

The result of this meta-analysis is the same with which of the Ariyaratnam $\mathrm{R}$ et al, ${ }^{36}$ ACE I/D polymorphism with a overall OR for the nine studies (a total of 3,572 individuals) of 1.90 (95\% CI 1.23 to 2.93) in Chinese. They only selected Englishlanguage articles for review and the genotype frequencies in control groups were not consistent with HWE. So control groups of our meta-analysis were more representative. Furthermore, we searched studies published in all language to eliminate language bias. One more earlier meta-analysis performed by Zhang et $\mathrm{al}^{5}$ suggested 58\% increase in risk of cerebral infarction in Han Chinese population. That meta-analysis included only 2066 individuals. With the publication of more recent studies, the result of this meta-analysis was more convincing, similar to a meta-analysis on Caucasians. ${ }^{37}$ The overall OR estimate for the five studies (1196 cases and 722 controls) is 1.31 (95\% CI 1.06 to $1.62 ; \mathrm{P}=0.01)$. It suggests that $\mathrm{ACE}$ genetic associations studies to date for cerebral infarction among persons of Han Chinese population are similar to Caucasians. Another similar meta-analysis on all ethnic populations was performed by Juan et al..$^{38}$ The ACE I/D polymorphism was evaluated in 11 studies (2990 cases and 11305 controls) and a summary OR of 1.21 (95\% CI 1.08 to 1.35). Might the differences in genetic effects among different ethnic populations for complex disorders such as stroke be overstated? The result should be validated by more studies on different ethnic populations.

The mechanisms underlying positive associations between the ACE I/D alleles and disease are not yet clear. Plasma and intracellular levels of ACE have been shown to be partly determined by the presence of the ACE I/D polymorphism in healthy individuals and in patients with stroke. ${ }^{39-42}$ Individuals homozygous for the D allele have a $56 \%$ increase in ACE activity compared with I allele homozygotes. ${ }^{43}$ The ACE converts angiotensin I to angiotensin II, which is known to be involved in vascular hypertrophy, vasoconstriction, and atherosclerotic processes. ${ }^{44}$ Also, ACE is responsible for degradation of bradykinin, a vasoactive peptide that has been suggested to stimulate vasodilator nitric oxide production. ${ }^{44}$

As with all meta-analysis, our analysis has limitations that must be considered when interpreting the findings. As no prospective studies have addressed our question, all included studies followed a retrospective case control design. Insufficient data were available for direct analysis of the influence of DD genotype on either stroke subtype or on stroke risk for different level of ACE. Only three studies ${ }^{7,10,28}$ explored the correlation between ACE gene and subtype of cerebral infarction. Two studies ${ }^{7,10}$ showed ACE gene might be an independent risk factor for both lacunar stroke and cerebral embolism. Another study ${ }^{28}$ showed ACE ID/DD genotypes didn't represented a significantly increased risk for either large-artery atherothromboembolic stroke or small-vessel thrombotic stroke. Only three studies $^{16,18,25}$ described the influence of DD genotype on stroke risk for different level of ACE. A few reviewed studies presented detailed information about interaction between ACE gene polymorphism and other factors such as age, ${ }^{30}$ gender,,${ }^{14}$ plasma lipid, ${ }^{22}$ smoking and alcohol consumption. ${ }^{28}$ Zhang et al ${ }^{16}$ reported that the ACE gene polymorphism might be related to position of damage. The mechanism remains unclear.

Based on known or presumed mechanisms of disease pathophysiology, candidate gene strategies provide a useful approach for evaluating gene-disease associations. However, candidate gene case-control studies have been criticized because of a lack of replication. Firstly, if another variant in or near the ACE I/D gene was the causal variant, the true association could easily be missed. Different linkage disequilibrium patterns with the functional variant may lead to variable results in different populations. Secondly, several cerebral infarction association studies have shown inconsistent results in Han Chinese population. Small sample size, study design flaws, population stratification, genotyping error, and other biases may be common reasons for the observed discrepancies between studies of genetic risks. Specific environmental exposures such as smoking or hypertension are another confounding factor for cerebral infarction with a strong gene environmental interaction in explaining the inconsistencies among observational studies. Interactions with other genetic or environmental factors have been discussed in a few studies.

Our data suggest that the ACE DD genotype may be a risk factor in the aetiology of cerebral infarction in Han Chinese population. The pooled ORs in this study of the ACE DD genotype suggest a modest but definite genetic effect. A large scale case-control study needs to be assessed to help answer the 
question of whether or not the polymorphism of the ACE I/D gene confers susceptibility to cerebral infarction.

\section{ACKNOWLEDGMENT}

The authors thank Dr. Shao for her valuable contribution and kindly revising the manuscript.

\section{REFERENCES}

1. Murray CJL, Lopez AD. Alternative projections of mortality and disability by cause 1990-2020: Global Burden of Disease Study. Lancet: 1997; 349: 1498-504.

2. Daemen MJ, Lombardi DM, Bosman FT, Schwartz SM. Angiotensin II induces smooth muscle cell proliferation in the normal and injured rat arterial wall. Circ Res. 1991; 68: 450-6.

3. Kato H, Suzuki H, Tajima S, Ogata Y, Tominaga T, Sato A, et al. Angiotensin II stimulates collagen synthesis in cultured vascular smooth muscle cells. J Hypertension. 1991; 9: 17-22.

4. Powell JS, Clozel JP, Muller RK, Kuhn H, Hefti F, Hosang M, et al. Inhibitors of angiotensin-converting enzyme prevent myointimal proliferation after vascular injury. Science.1989; 245: 186-8.

5. Zhang X, Xia JH, Jin DX, Zhou SJ, Zhu BL. Meta-analysis on the relationship between insertion/ deletion polymorphism of the angiotensin-converting enzyme gene and cerebral infarction in Chinese population. Zhejiang Med J. 2003; 25: 275-7.

6. Egger M, Smith GD, Schneider M, Minder C. Bias in meta-analysis detected by a simple, graphical test. BMJ. 1997; 315: 629-34.

7. BI S, Wang DS, Pan SH, Liu XM. Analysis of ACE gene deletion polymorphism in patients with ischemic cerebrovascular diseases. J Apoplexy Nerv Dis. 1998; 15: 81-3.

8. Song YL, Ding SY, Liu JY, Zhang YQ, Tao ZY, Hui RT, et al. The relationship between ischemic stroke accompanied with hypertension and insertion/deletion polymorphism of angiotensin-converting enzyme gene. Chin J Hypertens. 1998; 6: 99-102.

9. Xu YB, Wang XJ, Zhu JS, Wang YX, Dai LC. Angiotensin converting enzyme gene polymorphism and cerebrovascular disease. Chin J Neurol. 1998; 31:152-5.

10. He YS, Yao JL, Yue YL. A study on relationship between insertion/deletion polymorphism of angiotensin-converting enzyme gene and cerebrovascular disease. Chin J Clin Neurosci. 1997; 7: 78-82.

11. Chen XL, Ji HS, Yang A, Zhu DQ. Study on the polymorphism of angiotension converting enzyme gene in the patients with myocardial infarction cerebral infarction and glomerulonephropathy. Chin J Epidemiol. 2000; 21: 279.

12. Qiu XL, Zhang XL, Tang YJ, Study of ACE gene hypertension on mechanism of CVD. Mod Rehabil. 2000; 4: 1504-62.

13. Shi GF, L u Y, Tang JY. Study on the polymorphism of angiotension converting enzyme gene in the patients with cerebral infarction. J Clin Neurol. 2000; 13:19-21.

14. Zhang C, Zhou C, Luo BA. Study of ACE gene deletion polymorphism in patients with cerebraovascular disease. Acta Academiae Medicinae Qingdao Universitatis. 2000; 36: 85-7.

15. Cui TP, Zhao RS, Liu CQ, Jie CH, Wu JM. Polymorphism of the angiotens in-converting enzyme (ACE) and apolipoprote in exon 4 gene in patients of cererbal infarction. Chin J Gerontol. 2001; 21: 336-8.

16. Zhang X, Xia JH, Jin DX, Lin J, Ye HH. The relationship between angiotensin converting enzyme gene polymorphism and risk factors for cerebral infarction. Chin J Epidemiol. 2001; 22: 435-8.

17. Zhao Y, Ma LY, Liu YC, Wang QY, Liu LS. The relationship between angiotensin converting enzyme (ACE) gene I/D polymorphism and ischemic stroke. Shandong Med J. 2001; 41: 7-8.

18. Fan G, Fan WH, Wang CY. Study on the ACE activity and gene polymorphism in cerebral infarction. Shandong Med J. 2002; 42: 23 .
19. Yao LF, Liu LJ, Xu H, Gao HB. A preliminary study on the effect of angiotension converting enzyme gene polymorphism in the patients with cerebrovascular disease and its mechanism. Chin J Crit Care Med. 2002; 2: 585-6.

20. Zhang J, Sun XJ, Wen Q, Lv SQ. Relationship between angiotensin converting enzyme gene polymorphism and risk factors in cerebral infarction. Chin J Clin Neurosci. 2002; 10: 361-4 .

21. Gong YX, Pang XF, Zhu LM, Shen G, Shen BB. Study on the polymorph ism of angiotension converting enzyme gene in the patients with cerebral infarction in elderly. Chin J Gerontol. $2003 ; 23 ; 20-21$.

22. He JL, Wang YF, Wang YH, Wang XL, Chen P, Yang GA, et al. Relationship between I/D polymorphism of ACE gene and cerebrovascular diseases. J Clin Neurol. 2004; 17: 406-7.

23. Jiang HP, Chen JG, Tao ZY. ACE gene polymorphism distribution and sequence of patients who suffer from head obstruction. Chin J Med Lab Technol. 2004; 5: 567-8.

24. Pan QY, Sun XF, Liao BP, Li SY, Kong S. Analyisi of relation between angiotensin coverting enzyme (ACE) gene polymorphysim and cerebral infarction, cerebral hemorrhage. China Journal of modern Medicine. 2004;14: 50-2.

25. Yu Y, Luo DX, Li HL. Analysis of the polymorphism of angiotension converting enzyme gene in the patients with cerebral infarction. Chin J Public Health. 2004; 20: 1140-1.

26. Zhang YD, Qian M, Shi JP, Liu Y, Shi JP. A study on the relationship of angiotensin converting enzyme DTLs Polymorphism to cerebrovascular disease. J Brain Nerv Dis. 2004; $12: 322-5,345$.

27. Li X, Bu TX, Wang JH, Zhu XD. The analysis of angiotensin converting enzyme gene insertion/deletion polymorphism incerebral stroke. Chin J Lab Med. 2005; 28: 825-7.

28. Huo Y, Gao XG, Teng ZP, Ren ZH, Pan HF. Relationship between gene polymorphisms of angiotensin converting enzyme gene I/D, apolipoprotein E gene, $\beta$-fibrinogen 148C/T,N5,N10Methylene tetrahydrofolic acid reductase $677 \mathrm{C} / \mathrm{T}$ and cerebral Infarction. Chin J Stroke. 2006; 1: 846-51.

29. Luo YF, Yang CL, Tian GL. Association between angiotensin converting gene polymorphism and cerebral infarction. Guizhou Med J. 2006; 30: 318-20.

30. Yi XM, Guo T, Du YH, Ma BW, Zhang T. A study on relationship between ACE gene polymorphism and ischemic stroke in middle adults and young adults. Chongqing Med J. 2006; 35: 916-7,920.

31. Chen DQ, Xu E. Relationship between angiotensin converting enzyme gene polymorphism and a therosclerotic cerebral infarction. J Xinxiang Med College. 2007; 24: 465-7.

32. Cui JH, Yang G, Su XK, Shao Y, Liu DS. The relationship of angiotensinogen angiotensin-converting enzyme and endothelial nitric oxide synthase gene polymorphisms in predisposition to cerebral infarction. Chin J Gerontol. 2007; 27: 2197-9.

33. Gu GH, Shi JF, Pu JH, Lu LL. A study on relationship between ACE gene polymorphism and cardio-cerebrovascular disease in the elderly. Chin J Clin Lab Sci . 2007; 25: 413-5.

34. Li CM, Zhang C, Lu XL, Feng HY, Zeng Y, Zhang HL, et al. Association between angiotensin-converting enzyme and polymorphisms of N5, N10 -Methylene tetrahydrofolic acid reductase gene in patients with ischemic stroke. Acta Academiae Medicinae Sinicae. 2007; 29: 359-63.

35. Lv J, Qu F, Wang JH, Cao DS. The relationship of angiotensinconverting enzyme gene polymorphisms in acute cerebrovascular disease. Harbin Med J. 2007; 27:1-3.

36. Ariyaratnam R, Casas JP, Whittaker J, Smeeth L, Hingorani AD, Sharma P. Genetics of ischaemic stroke among persons of nonEuropean descent: a meta-analysis of eight genes involving approximately 32,500 individuals. PLoS Med. 2007; 4: 728-36.

37. Sharma P. Meta-analysis of the ACE gene in ischaemic stroke. J Neurol Neurosurg Psychiatry. 1998; 64: 227-30.

38. Juan P, Casas MD, Aroon D. Meta-analysis of genetic studies in ischemic stroke. Thirty-two genes involving approximately 18000 cases and 58000 controls. Arch Neurol. 2004; 61: $1652-61$. 
39. Rigat B, Hubert C, Alhenc-Gelas F, Cambien F, Corvol P, Soubrier F. An insertion/deletion polymorphism in the angiotensin1converting enzyme gene accounting for half the variance of serum enzyme levels. J Clin Invest. 1990; 86:1343-6.

40. Rigat B, Hubert C, Corvo P, Soubrier F. PCR detection of the insertion/deletion polymorphism of the human angiotensin converting enzyme gene (DCP1) (dipeptidy 1 carboxypeptidase 1). Nucleic Acids Res. 1992; 20: 1433.

41. Tiret L, Rigat B, Visvikis S, Breda C, Corvol P, Cambien F, et al. Evidence from combined segregation and linkage analysis that a variant of the angiotensin I-converting enzyme (ACE) gene controls plasma ACE levels. Am J Hum Genet. 1992; 51: 197-205.
42. Sharma P, Carter ND, Barley J, Lunt R, Seymour CA, Brown MM. Polymorphisms in the gene encoding angiotensin 1-converting enzyme and relationship to its post-translational product in cerebral infarction. J Hum Hypertens. 1994; 8: 633-4.

43. Agerholm-Larsen B, Nordestgaard BG, Tybjaerg-Hansen A. ACE gene polymorphism in cardiovascular disease: meta-analyses of small and large studies in whites. Arterioscler Thromb Vasc Biol. 2000; 20: 84-92.

44. Kim S, Iwao H. Molecular and cellular mechanisms of angiotensin II-mediated cardiovascular and renal diseases. Pharmacol Rev. 2000; 52: 11-34. 